\title{
Percentages of NKT cells in the tissues of patients with non-small cell lung cancer who underwent surgical treatment
}

\author{
Maria Pyszniak ${ }^{1}$, Paweł Rybojad ${ }^{2}$, Katarzyna Pogoda ${ }^{1}$, Andrzej Jabłonka², Agnieszka Bojarska-Junak ${ }^{1}$, \\ Jacek Tabarkiewicz ${ }^{1}$ \\ ${ }^{1}$ Chair and Department of Clinical Immunology, Medical University of Lublin, Poland \\ ${ }^{2}$ Chair and Department of Thoracic Surgery, Medical University of Lublin, SPSK 4, Lublin, Poland \\ Kardiochirurgia i Torakochirurgia Polska 2014; 11 (1): 34-39
}

\begin{abstract}
Introduction: Natural killer T (NKT) cells are involved in the antitumor response by direct cytotoxicity and indirectly through activation of effector cells. Recent studies have shown a relationship between the number and function of NKT cells and clinical outcomes. NKT cells seem to represent a promising tool for immunotherapy of cancer.

The aim of the study was to evaluate the distribution of NKT cells in peripheral blood, lymph nodes and tumor tissue of non-small cell lung cancer (NSCLC) patients, as well as development of the most efficient set of cytokines stimulating differentiation of NKT cells.

Material and methods: We evaluated the percentage of iNKT+CD3+ cells in the tissues collected from patients with NSCLC. For the generation of NKT cells, we cultured cells isolated from the blood of 20 healthy donors and from the tissues of 4 NSCLC patients. Cells were stimulated with $\alpha$-GalCer in combinations with cytokines.

Results: We noted significant differences in the percentages of NKT cells in the patients' tissues. The highest percentage of these cells was observed in the tumor tissue and the lowest in the lymph nodes. In vitro, in healthy donors all $\alpha$-GalCercytokine combinations were effective in stimulation of NKT cells' proliferation. NKT cells' proliferation was the most efficiently stimulated by $\alpha$-GalCer+IL-2+IL-7 and $\alpha$-GalCer+IL-2+ + IFN- $\gamma$.

Conclusions: Our results suggest that in the course of NSCLC, NKT cells migrate to the primary tumor and accumulate therein. All tested combinations of $\alpha$-GalCer and cytokines were capable of generation of NKT cells in vitro.
\end{abstract}

Key words: NSCLC, NKT, peripheral blood, lymph nodes, tumor.

\section{Streszczenie}

Wstęp: Komórki NKT biorą udział w odpowiedzi przeciwnowotworowej na drodze bezpośredniej cytotoksyczności oraz pośrednio poprzez aktywację komórek efektorowych. Ostatnie badania wykazały zależność pomiędzy liczbą i funkcją komórek NKT a rokowaniem klinicznym. Wydają się stanowić obiecujące narzędzie w immunoterapii nowotworów, jednakże ich mała liczba w ludzkim organizmie, a szczególnie obniżona u chorych na raka, sugeruje konieczność generacji tej populacji komórkowej.

Celem pracy była ocena dystrybucji komórek NKT we krwi obwodowej, węzłach chłonnych i tkance guza u pacjentów z niedrobnokomórkowym rakiem płuc (NDRP) oraz opracowanie najbardziej wydajnego zestawu cytokin stymulującego różnicowanie komórek NKT.

Materiat i metody: Za pomocą cytometrii przepływowej autorzy oceniali odsetek komórek iNKT+CD3+ w tkankach pobranych od 18 pacjentów z NDRP. W celu generacji komórek NKT zakładano hodowle komórek wyizolowanych z krwi 20 zdrowych dawców oraz z tkanek 4 pacjentów z NDRP. Komórki były stymulowane $\alpha$-GalCer $w$ następujących kombinacjach: $\alpha$-GalCer+IL-2, $\alpha$-GalCer+IL-2+IL-7 oraz $\alpha$-GalCer+IL-2+IFN- $\gamma$. Wyniki: Odnotowano istotne statystycznie różnice pomiędzy odsetkami komórek NKT w tkankach pacjentów. Najwyższy odsetek tych komórek zaobserwowano w tkance guza (0,39\%), a najniższy w węzłach chłonnych $(0,13 \%)$. Wszystkie zastosowane kombinacje $\alpha$-GalCer i cytokin stymulowały proliferację komórek NKT u zdrowych dawców w warunkach in vitro. Kombinacje: $\alpha$-GalCer+IL-2+IL-7 oraz $\alpha$-GalCer+IL-2+IFN- $\gamma$, stymulowały proliferację komórek NKT z najlepszą wydajnością.

Wnioski: Wyniki sugerują, że komórki NKT migrują do guza pierwotnego i gromadzą się w nim. Wszystkie badane kombinacje $\alpha$-GalCer i cytokin były zdolne do generacji komórek NKT in vitro.

Słowa kluczowe: NDRP, NKT, krew obwodowa, węzły chłonne, guz.

Address for correspondence: dr Paweł Rybojad, Katedra i Klinika Chirurgii Klatki Piersiowej, Uniwersytet Medyczny w Lublinie, ul. Jaczewskiego 8 , 20-954 Lublin, phone: +48 6079229 54, e-mail: rybojad@wp.pl 


\section{Introduction}

Lung cancer is the most common malignancy in the world [1]. It is estimated that nearly $90 \%$ of all cases of lung cancer are the result of active cigarette smoking. Other cases are associated with exposure to physical and chemical environmental and occupational factors, such as arsenic, asbestos or radon [2]. Non-small cell lung cancer (NSCLC) accounts for over $80 \%$ of all lung malignancies [1]. In most cases, lung cancer develops asymptomatically for a long time, which contributes to the late diagnosis and high advancement of the disease and makes it unsuitable for surgical treatment. These are the reasons for the low 5 -year survival rate, which is estimated at around $8-16 \%$ [3]. Unsatisfactory treatment results encourage scientists to search for new therapies intensively. In this perspective, special attention is turned to natural killer T (NKT) lymphocytes. NKT cells are a special heterogeneous subpopulation, demonstrating co-expression of the characteristics of both conventional T lymphocytes ( $\alpha \beta T C R, C D 3)$ and NK cell surface markers (CD56, CD161) $[4,5]$. Thanks to their ability, regarding regulation of functions and activity of T cells and NK cells, NKT cells seem to play a pivotal role in combining innate and acquired immunity [6]. Contrary to classical T lymphocytes, which can recognize only peptide antigens, NKT are able to recognize lipid or glycolipid antigens presented in the context of the non-classical antigen-presenting molecule CD1d. Therefore, they fill a gap in the repertoire of antigens which can be recognized by human lymphocytes [7]. A breakthrough in the study on NKT cells was the discovery of the first agonist of invariant TCR ( $T$ cell receptor), $\alpha$-galactosylceramide ( $\alpha$-GalCer), which is a glycosphingolipid isolated from the marine sponge Agelas mauritianus and is commonly used in vitro for the identification and activation of iNKT (invariant-NKT) cells [4, 5, 8]. Although numerous studies have proved that $\mathrm{V}_{\alpha 2} 24 \mathrm{NKT}$ cells demonstrate antitumor activity in the mechanism of cytotoxicity $[6,7]$, their main role is to activate other cells of the immune system, such as NK cells, CD8+ T cells, cytotoxic T lymphocytes (CTL) and dendritic cells $[6,7]$.

In animal models it was demonstrated that after activation with exogenous $\alpha$-GalCer, NKT cells have the ability to inhibit tumor growth and metastasis [7]. Decrease of the number and activity of NKT was reported in different types of neoplasms, including melanoma and colorectal, head and neck, breast and kidney cancers [7, 9]. Some researchers even postulate that NKT cells can be used as predictive factors in cancer $[9,10]$. Although most of the evidence for the antitumor effect of NKT cells is based on animal models, numerous attempts have been made with their clinical application [11, 12]. They are based on three main strategies: in vivo activation of iNKT cells following intravenous administration of $\alpha$-GalCer; reinfusion of autologous dendritic cells loaded with $\alpha$-GalCer ex vivo; and intravenous administration of autologous iNKT cells which were stimulated ex vivo. Patients who underwent therapy with iNKT cells showed a good response to the treatment. There were no serious side effects. Most importantly, there was a significant increase in the number of NKT cells and the production of IFN- $\gamma$ and long-term disease stabilization with a good quality of life. Additionally, prolonged survival was observed in patients who responded to the treatment with increased IFN expression [6, 7, 11-13].

\section{Aim of the study}

The purpose of our study was to evaluate the distribution of NKT cells in peripheral blood, lymph nodes and tumor tissue of patients with non-small cell lung cancer. The second objective was to develop the best set of substances capable of inducing NKT generation, in vitro.

\section{Material and methods}

Material for assessment was obtained from 18 male patients with non-small cell lung cancer hospitalized in the Department of Thoracic Surgery, Medical University of Lublin. All subjects gave informed consent to participate in the study. Among the subjects there were 9 patients with squamous cell carcinoma, 6 with adenocarcinoma and 3 with large cell carcinoma. The tissue material consisted of peripheral vein blood samples, fragments of lymph nodes and tumor resected in the course of thoracic surgery. All 18 participants reported a smoking habit and six of them were still under its influence at the time of diagnosis. The mean age of the patients was $62.4 \pm 8.4$ years. Within 30 months after surgery nearly $25 \%$ of evaluated patients died. For generation of NKT cells, we collected blood samples from 20 healthy donors and 4 patients with NSCLC. Additionally fragments of lymph nodes and tumor tissue were obtained from patients.

Assessment of NKT cells' distribution in the blood, lymph nodes and tumor tissue.

Monomorphonuclear leukocytes from peripheral blood, lymph nodes and tumor tissue were isolated and preserved as described before [14]. The percentages of iNKT cells in the tissues were evaluated using a Becton Dickinson FACSCalibur flow cytometer (BD Biosciences, USA). The measurements were performed after incubation of the cells with anti-invariant NKT and anti-CD3 antibodies, conjugated to fluorescein isothiocyanate (FITC) and phycoerythrin (PE) (both: BD Pharmingen ${ }^{\mathrm{TM}}$, USA), respectively. Data collection and analysis was performed using CellQuest Pro software.

\section{Generation of iNKT cells in vitro with different combinations of cytokines}

Monomorphonuclear cells' isolation was performed with the methods described above. Cells were suspended in culture medium: Gibco AIM-V serum-free (Life Technologies, USA). Unstimulated cells served as a control culture. Other cultures were stimulated with $\alpha$-GalCer (Enzo Life Sciences, USA) and cytokines (BioVision Inc., USA) in the following combinations: I: $\alpha$-GalCer+IL-2, II: $\alpha$-GalCer+IL-2+ + IL-7, III: $\alpha$-GalCer+IL-2+IFN- $\gamma$. Cells were cultured at $37^{\circ} \mathrm{C}$, $5 \% \mathrm{CO}_{2}$ and $95 \%$ humidity in a New Brunswick Galaxy $170 \mathrm{R}$ 
incubator. Seven days after culture initiation, their medium was replaced and the same set of stimulators was added. After that cells were incubated for another 7 days. On the last day of culture, the percentage of iNKT+CD3+ cells was assessed by the method described above.

\section{Statistical analysis}

Statistical analysis was performed using Statistica 10.0 $\mathrm{PL}$ software. The results are presented as median and interquartile range (IQR). Friedman ANOVA test followed by with post-hoc tests, Mann-Whitney $U$ test, Kruskal-Wallis test followed by Dunn test and Spearman rank correlation were used for analysis of statistical significance. Results were considered as significant at the significance level $p<0.05$.

\section{Results}

The aim of the study was to evaluate the distribution of NKT cells in peripheral blood, lymph nodes and tumor tissue in patients with non-small cell lung cancer. Statistical analysis of obtained results revealed significant differences in the distribution of NKT cells in different tissues. The highest percentage of these cells was observed in the tumor tissue $(0.39 \%)$ and the lowest in the lymph nodes $(0.13 \%)(p=0.002)$. Comparison of the number of NKT cells in peripheral blood of healthy donors and NSCLC patients showed some differences $(0.25 \%$ and $0.24 \%$ respectively), but they were not statistically significant $(p=0.9)$. Percentages of NKT cells among the lymphocytes presented in particular tissues are shown in Figure 1.

The obtained results were subsequently compared with patients' clinical parameters. Using the Kruskal-Wallis test, it was demonstrated that there are significant differences in the percentages of NKT cells in the peripheral blood $(p=0.04)$ and lymph nodes $(p=0.02)$ depending on the histologic type of NSCLC. Statistical analysis proved that the highest percentage of NKT cells was in squamous cell carcinoma and the lowest in adenocarcinoma. Similar differences were not observed in the tumor tissue. Although

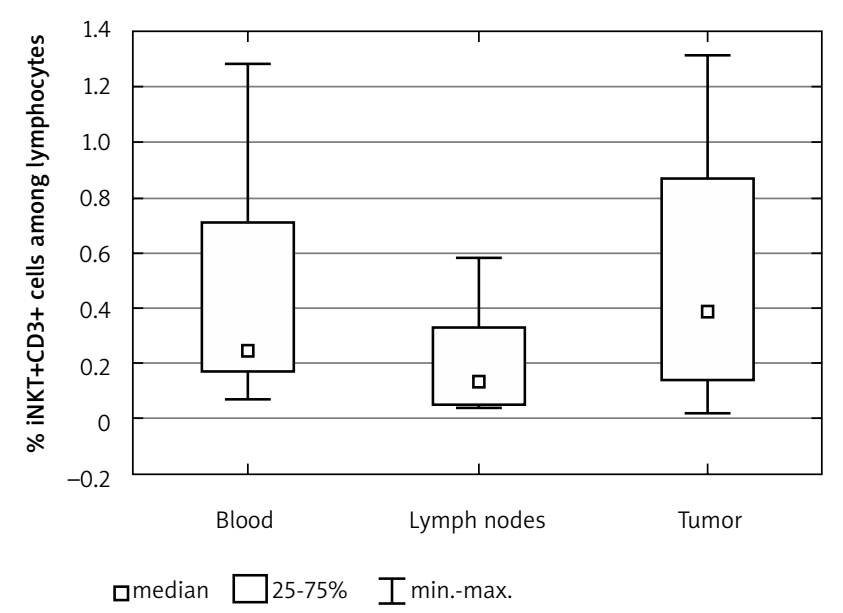

Fig. 1. Percentage of iNKT+CD3+ in examined tissues no relationship between the cancer staging and number of NKT cells in the studied tissues was revealed, it was demonstrated that the number of NKT cells in the peripheral blood increases depending on the size of the primary tumor (T stage). The proportion of NKT cells was the lowest in the blood of patients with stage T1 of the disease and the highest in the blood of T4 patients $(p=0.03)$. The percentage of NKT cells among peripheral blood lymphocytes is shown in Figure 2.

The above relationship was not observed in the lymph nodes or tumor tissue. Mann-Whitney $U$-test analysis showed no significant difference in the percentage of NKT cells in the studied tissues and N stage. Although a higher percentage of NKT cells was observed in evaluated tissues of patients who died in the period between surgery and the end point of the study, these results did not reach the expected level of significance. The correlation between the number of NKT cells and clinical characteristics of patients (age, WBC level, period of time since smoking cessation, smoking period and the number of pack-years) did not show any statistical significance.

The second objective of this experiment was to develop a combination of $\alpha$-GalCer and cytokines which would be capable of generating NKT cells in vitro. In the tissues of healthy donors there were statistically significant differences in the percentages of NKT cells in the cultures stimulated with different sets of cytokines and control culture $(p=0.001)$. When compared to the control culture the largest increase in the percentage of NKT cells was observed in the cultures stimulated with $\alpha-G a l C e r+I L-2+I L-7$ and $\alpha$-GalCer+IL-2+IFN- $\gamma$. The results are presented in Figure 3.

Analysis of mononuclear cell cultures from peripheral blood, lymph nodes and tumor tissues of NSCLC patients showed no significant difference in the percentage of NKT cells in the cultures stimulated with different combinations of cytokines and control culture. Comparison of stimulation indices after pacing with individual combinations of cytokines, both in healthy donors and NSCLC patients, showed no statistically significant differences between cultures.

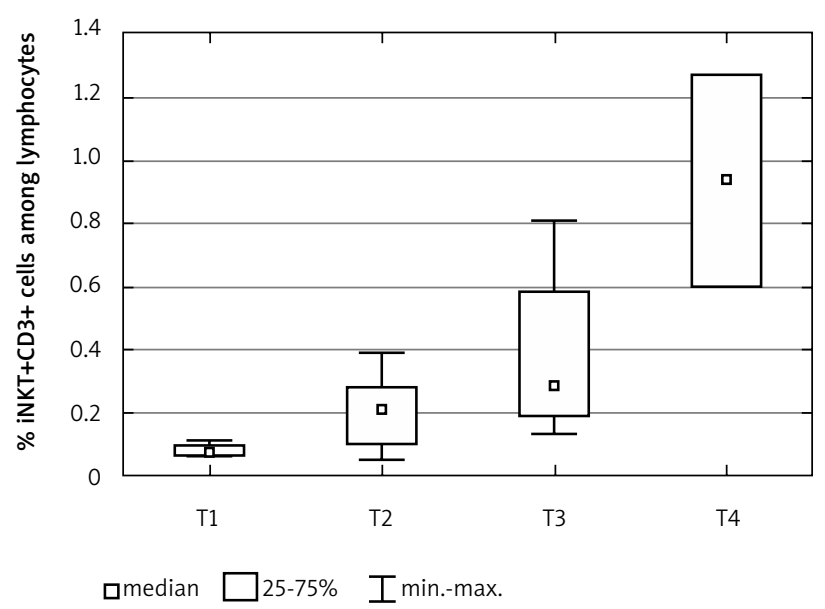

Fig. 2. Association between percentage of iNKT+CD3+ and advancement of primary tumor 


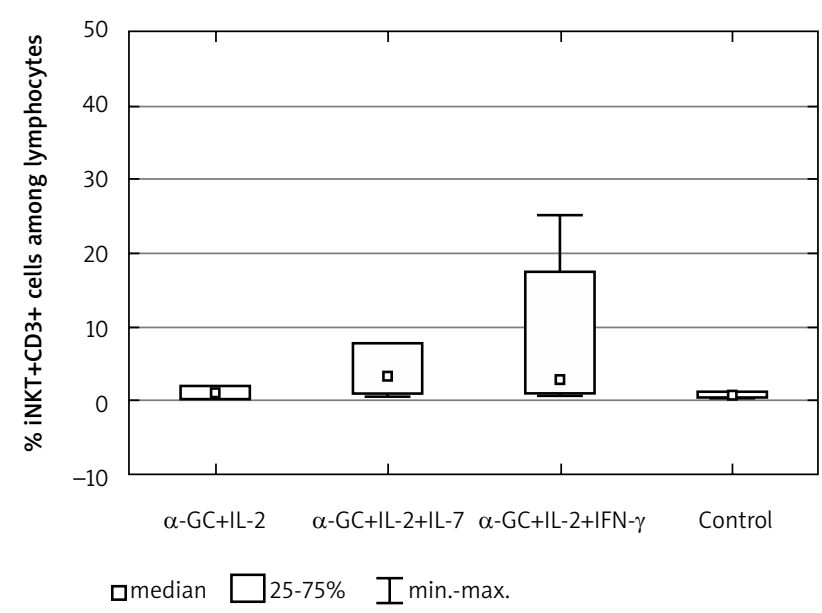

Fig. 3. Efficiency of NKT cell generation in cultures stimulated with $\alpha$-GalCer $(\alpha-G C)$ and different cytokines

\section{Discussion}

Lung cancer is the most common malignancy in the world, characterized by a very poor prognosis and high mortality in both men and women [1]. For this reason, many attempts are undertaken worldwide to improve the diagnostic and therapeutic techniques. In recent years, great hopes are associated with the use of immunological methods to improve predictive factors and therapeutic procedures. In our study, we observed a significantly higher percentage of NKT cells in tumor tissue as compared to the blood and lymph nodes of NSCLC patients. The results suggest that NKT cells migrate to the tumor environment and are accumulated therein. The mechanism of this phenomenon is not completely explained, but some reports suggest that it may be associated with chemokines secreted by tumor cells and their complementary receptors on NKT cells [15]. The results of the majority of research focused on this problem have confirmed the hypothesis about the migration of NKT cells to the tumor environment [16-18]. Motohashi et al. [16] observed a significant deficiency of $\mathrm{V} \alpha 24$ NKT cells in the peripheral blood of lung cancer patients and a much higher percentage of these cells in the tumor environment compared to tissues of the control group. Bricard et al. also observed an increased number of NKT cells in tumor tissue of patients with hepatocellular carcinoma [18].

It is suggested that the accumulation of NKT cells in the tumor may correlate with a better prognosis. Tachibana et al. [17] reported that immunohistochemical staining of cells present in the primary tumor environment revealed the presence of activation markers (CD69 or FasL) and effector molecules (IFN- $\gamma$ and granzyme B), providing evidence of their direct cytotoxic activity against tumor cells. Additionally, in the same study they found an increased number of NKT cells in the neighboring, metastasis-free lymph nodes, suggesting their role in the inhibition of metastasis. Patients with a higher number of NKT cells had a longer overall survival time and progression-free time [17].

In our study we compared the number of circulating NKT cells in the blood of NSCLC patients and healthy do- nors. There were no significant differences between groups. Similar results were obtained by Crough et al. [19]. However, most of the available studies demonstrated the deficit of NKT cells in the blood of cancer patients, compared to the blood of healthy donors $[16,20,21]$. The reason for such differences may be too small groups of studied patients.

We found a relationship between histological type of tumor and the number of NKT cells in the blood and lymph nodes of patients. The largest iNKT cell percentage was in patients with squamous cell carcinoma, and the lowest in those with adenocarcinoma. This seems interesting, considering the fact that the glandular type of NSCLC is associated with a worse prognosis than squamous cell carcinoma. Our study showed no correlation between the number of NKT cells and clinical stage of the disease, which is consistent with results of other researchers [16]. However, detailed analysis of the individual parameters of TNM classification showed that the size of the tumor ( $T$ ) was directly related to the number of blood circulating NKT cells. Interestingly, we did not find such a dependence for NKT in the tumor tissue.

In the literature there are reports on the impact of aging on the number of NKT cells, which declines in the blood of older patients $[19,20]$. Reduction in the level of circulating NKT cells can serve as a risk factor for cancer development. Our study did not demonstrate any correlation between the age of patients and the number of NKT cells.

In recent years, new promising therapeutic methods have been introduced. Some of them are based on immunological interactions. Due to their low abundance in human tissues, use of NKT cells in cancer immunotherapy requires the development of cell generation methods on a large scale. The second objective of our study was to develop a set of cytokines best suited for in vitro stimulation of NKT cells' differentiation. As the stimulators, we used sets of cytokines composed of $\alpha$-GalCer and IL-2, whose effectiveness has been proven in previous studies [19, 22] Crough et al. tried to generate human NKT cells in vitro, using $\alpha$-GalCer and IL-2. After 7 days of PBMC culture, they obtained a significant increase of NKT cells in cultures of cells obtained from healthy donors and from NSCLC patients [19].

Additionally, in our study, we used IL-7 and IFN- $\gamma$ to enrich PBMC cultures to maintain normal development and function of NKT cells. Physiologically dendritic cells secrete IL-7 to affect the proper maturation of NKT cells after leaving the thymus [7] and IFN- $\gamma$ is produced by activated NKT lymphocytes and stimulates NK cells, macrophages and cytotoxic T lymphocytes [6, 7]. NKT stimulation efficiency of IL-7 was shown by van der Vliet et al. in an experiment in which they obtained a 76-fold increase in the number of NKT cells after their culture in the presence of $\alpha$-GalCer-DC, IL-7 and IL-15 [23].

We found that all combinations of $\alpha$-GalCer and cytokines stimulate proliferation of NKT cells in the healthy donors. The highest increase in cell numbers was observed in the cultures stimulated by the combinations $\alpha-\mathrm{GalCer+IL-2+IL-7}$ 
and $\alpha$-GalCer+IL-2+IFN- $\gamma$. These results are consistent with the majority of similar trials $[19,22]$ and confirm the hypothesis that IL-7 promotes the maturation and differentiation of NKT cells [23]. Unlike healthy donors, cultures of mononuclear cells obtained from the tissues of lung cancer patients did not show an increase in the number of NKT cells. In a similar study Yanagisawa et al. [22] did not observe growth of an NKT cell population after being cultured in the presence of $\alpha$-GalCer and IL-2 for seven days. Only cultures previously sorted in order to maintain V $\alpha 24$ NKT cells resulted in a significant increase in their number. It is possible that the low proliferative potential of these cells in cancer patients might be related to the presence of immunosuppressive agents which inhibit NKT cells' differentiation in these tissues. There are also reports that the deficit of NKT cells in the tissues of patients can be associated with decreased proliferation after stimulation with $\alpha$-GalCer [21]. At the same time, it has to be stressed that our study was conducted on a very small number of patients and therefore it needs to be expanded.

Our findings demonstrating the migration and accumulation of iNKT cells in the tumor tissue make it necessary to investigate the mechanisms responsible for this phenomenon and the influence of iNKT cells on tumor cells. In addition, promising results of iNKT cell generation in healthy donors and simultaneous absence of satisfactory results in NSCLC patients suggest the need to repeat this study on a larger number of patients.

\section{Conclusions}

The highest percentage of NKT cells was detected in the tumor tissue and the smallest in the lymph nodes. This result suggests that NKT cells migrate to and accumulate in the environment of the primary tumor. There is a correlation between the histological type of lung cancer and the number of NKT cells. The highest percentage of NKT cells was observed in patients with squamous cell carcinoma and the lowest in patients with adenocarcinoma. This observation is consistent with the statement that adenocarcinomal type of NSCLC is characterized by a worse prognosis than squamous cell type. The number of NKT cells in the blood of lung cancer patients increases with the size of the primary tumor - T stage in the TNM classification. All cytokines and $\alpha$-GalCer combinations used stimulated the proliferation of NKT cells in healthy donors in vitro. The most efficient stimulation of NKT proliferation was achieved by the use of the following combinations: $\alpha$-GalCer+IL-2+IL-7 and $\alpha$-GalCer+IL-2+IFN- $\gamma$.

\section{Acknowledgments}

The research was supported by MNiSW grant no. NN402439139 and Medical University of Lublin grant no. DS460.

The study was developed using the equipment purchased within the Project: "The equipment of innovative laboratories doing research of new medicines used in the therapy of civilization and neoplastic diseases" within Op- erational Program Development of Eastern Poland 20072013, Priority Axis I Modern Economy, Operations I.3 Innovation Promotion.

\section{References}

1. Abbasi S, Badheeb A. Prognostic Factors in Advanced Non-Small-Cell Lung Cancer Patients: Patients Characteristics and Type of Chemotherapy. Lung Cancer Int 2011; http://dx.doi.org/10.4061/2011/152125.

2. Luo J, Hendryx M, Ducatman A. Association between Six Environmental Chemicals and Lung Cancer Incidence in the United States. J Environ Public Health 2011; http://dx.doi.org/10.1155/2011/463701.

3. Ghosal R, Kloer P, Lewis KE. A review of novel biological tools used for screening for the early detection of lung cancer. Postgrad Med J 2009; 85: 358-363.

4. Matsuda JL, Mallevaey T, Scott-Browne J, Gapin L. CD1d-restricted iNKT cells, the "Swiss-Army knife" of the immune system. Curr Opin Immunol 2008; 20: 358-368.

5. Bojarska-Junak A, Tabarkiewicz J, Rolinski J. Komórki NKT: powstanie, mechanizmy i efekty działania. Postepy Hig Med 2013; 67: 65-78.

6. Terabe M, Berzofsky JA. The role of NKT cells in tumor immunity. Adv Cancer Res 2008; 101: 277-348.

7. Tan JQ, Xiao W, Wang L, He YL. Type I natural killer T cells - naturally born for fighting. APS 2010; 31: 1123-1132.

8. Pilones AK, Aryankalayil J, Demaria S. Invariant NKT cells as targets for immunotherapy in solid tumors. Clin Dev Immunol 2012; doi:10.1155/2012/720803.

9. Metelitsa LS. Anti-tumor potential of type-I NKT cells against CD1d-positive and CD1d-negative tumors in humans. Clin Immunol 2011; 140: 119-129.

10. Molling JW Langius JAE, Langendijk JA, Leemans CR, BontkesHJ, van der Vliet HJJ, von Blomberg BME, Scheper RJ, van den Eertwegh AJM. Low levels of circulating invariant natural killer T cells predict poor clinical outcome in patients with head and neck squamous cell carcinoma. J Clin Oncol 2007; 25: 862-868.

11. Ishikawa A, Motohashi S, Ishikawa E. A phase I study of alpha-galactosylceramide (KRN7000)-pulsed dendritic cells in patients with advanced and recurrent non-small cell lung cancer. Clin Cancer Res 2005; 11: 1910-1917.

12. Motohashi S, Ishikawa A, Ishikawa E. A phase I study of in vitro expanded natural killer T cells in patients with advanced and recurrent non-small cell lung cancer. Clin Cancer Res 2006; 12: 6079-6086.

13. Motohashi S, Okamoto Y, Yoshino I, Nakayama T. Antitumor immune responses induced by iNKT cell-based immunotherapy for lung cancer and head and neck cancer. Clin Immunol 2011; 140: 167-176.

14. Rybojad P, Jabłonka A, Wilczyńska B, Tabarkiewicz J. Surgery decreases number of cells secreting cytotoxic mediators and increases secretion of interleukin 10 in patients with lung cancer. Eur J Surg Oncol 2013; 39: 12691277.

15. Metelitsa LS, Wu HW, Wang H, Yang Y, Warsi Z, Asgharzadeh S, Groshen S, Wilson SB, Seeger RC. Natural killer T cells infiltrate neuroblastomas expressing the chemokine CCL2. J Exp Med 2004; 199: 1213-1221.

16. Motohashi S, Kobayashi S, Ito T, Magara KK, Mikuni O, Kamada N, lizasa T, Nakayama T, Fujisawa T, Taniguchi M. Preserved IFN- $\alpha$ production of circulating Va24 NKT cells in primary lung cancer patients. Int J Cancer 2002; 102: 159-165.

17. Tachibana T, Onodera H, Tsuruyama T, Mori A, Nagayama S, Hiai H, Imamura M. Increased intratumor Valpha24-positive natural killer T cells: a prognostic factor for primary colorectal carcinomas. Clin Cancer Res 2005; 11: 7322-7327.

18. Bricard G, Cesson V, Devevre E, Bouzourene H, Barbey C, Rufer N, Im JS, Alves PM, Martinet O, Halkic N, Cerrotini JC, Romero P, Porcelli SA, Magdonald HR, Speiser DE. Enrichment of Human CD4+ Va24/Vb11 Invariant NKT Cells in Intrahepatic Malignant Tumors. J Immunol 2009; 182: 5140-5151.

19. Crough T, Purdie TM, Okai M, Maksoud A, Nieda M, Nicol AJ. Modulation of human $\mathrm{V} \alpha 24+\mathrm{V} \beta 11+\mathrm{NKT}$ cells by age, malignancy and conventional anticancer therapies. Br J Cancer 2004; 91: 1880-1886.

20. Molling JW, Kölgen W, van der Vliet HJJ, Boomsma MF, Kruizenga H, Smorenburg CH, Molenkamp MG, Langendijk JA, Leemans CR, von Blomberg BME, Scheper RJ, van den Eertwegh AJM. Peripheral blood IFN- $\gamma$-secreting Va24Vb11NKT cell numbers are decreased in cancer patients independent of tumor type or tumor load. Int J Cancer 2005; 116: 87-93. 
21. Tahir SM, Cheng O, Schaulov A, Koezuka Y, Bubley GJ, Wilson SB, Balk SP, Exley MA. Loss of IFN- $\gamma$ production by invariant NKT cells in advanced cancer. J Immunol 2001; 167: 4046-4050.

22. Yanagisawa K, Seino K, Ishikawa Y, Nozue M, Todoroki T, Fukao K. Impaired proliferative response of Va24 NKT cells from cancer patients against $\alpha$-galactosylceramide. J Immunol 2002; 168: 6494-6499.

23. van der Vliet HJ, Nishi N, Koezuka Y, von Blomberg BME, van den Eertwegh AJM, Porcelli SA, Pinedo HM, Scheper RJ, Giaccone G. Potent expansion of human natural killer T cells using $\alpha$-galactosylceramide (KRN7000)-loaded monocyte-derived dendritic cells, cultured in the presence of IL-7 and IL-15. J Immunol Methods 2001; 247: 61-72. 